\title{
REDD+ IN THE PHILIPPINES: LEGAL STATUS AND CONSERVATION OF MANGROVE FORESTS IN THE PHILIPPINES
}

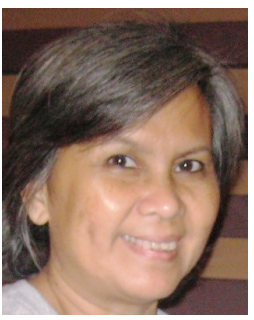

\section{Gloria Estenzo Ramos}

Environmental Law Professor, University of Cebu College of Law Philippines

\begin{abstract}
Rose Liza Eisma Osorio Environmental Law Professor University of Cebu College of Law Philippines
\end{abstract}

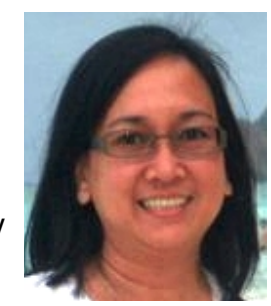

Mangroves perform a crucial role in maintaining the ecological integrity of the coastal ecosystem. They act as filters in the coastal zone, preventing the damaging effects of upland sediments on seagrass beds and coral reefs, minimise the effects of storm surges and act as carbon sinks that mitigate climate change. These essential services, however, are degraded through indiscriminate cutting, conversion of mangrove swamps to fishponds, reclamation projects and other coastal developments and pollution. Experts reveal that the Indo-Malay Philippine Archipelago has one of the highest rates of mangroves loss. From an estimated 500,000 hectares of mangrove cover in 1918, only 120,000 hectares of mangroves remain in the Philippines today.

The country has had the legal and policy framework to protect and conserve mangroves. But weak implementation of laws, overlapping functions among agencies and, in general, poor management by the people and local governments have hindered the sustainable management of mangrove forests.

Positive developments, however, are taking place with the promulgation of laws on climate change and executive orders which specifically include mangrove and protected areas under the National Greening Program (NGP) and addresses equity, food security and poverty issues by giving preference to NGP beneficiary communities as a priority in the Conditional Cash Transfer (CCT) Program. Moreover, participatory Planning and Multi-stakeholder Approaches are among the strategies contemplated by the Philippine National REDD + Strategy.

The article examines the implementation and effects of the Philippine National REDD+ Strategy, the National Climate Change Action Plan which specifically integrates REDD+ and ecosystem valuation into decision-making, and the executive orders which support the mainstreaming of the National Greening Program.

\section{Introduction}

Mangroves are the true rainforests of the Philippine coastline. With at least 40 species out of the 54 known species worldwide, ${ }^{1}$ mangroves are among the most biologically-diverse coastal ecosystems in the country. However, an estimated 70 per cent of the original mangrove forests has been lost, reduced from an estimated 400,000-500,000 hectares in the early $1900 \mathrm{~s}^{2}$ to only 109,700 hectares in $2000 .^{3}$ Huge losses in mangrove forest cover are primarily attributed to conversion of the land into fishponds for aquaculture production and overexploitation for mangrove-derived products such as charcoal, firewood and timber. ${ }^{4}$

\footnotetext{
1 J Primavera, 'Development and Conservation of Philippine Mangroves: Institutional Issues' (2000) 35(Special Issue) Ecological Economics 91.

2 W Brown and A Fisher, 'Philippine Mangrove Swamps. Minor Forest Products of the Philippines' (1920) 1 (22), Bureau of Forestry Bulletin 18 <http://www.archive.org/stream/minorproductsofp01brow/minorproductsofp01brow_djvu.txt>.

3 M L Wilkie and S Fortuna, 'Status and Trends in Mangrove Area Extent Worldwide' (Forest Resources Assessment Working Paper No 63, Forest Resources Division, FAO, December 2003) <http://www.fao.org/docrep/007/j1533e/J1533E00.htm>.

$4 \mathrm{~J}$ H Primavera, 'Management and Conservation of Mangroves in the Philippines' in Joint UNU-Iwate-UNESCO International Conference (8-13 July 2002) <http: / / landbase.hq.unu.edu/Conference/Abstracts/Primavera.htm> .
} 
Mechanisms to address the ongoing mangrove deforestation such as the Reducing Emissions from Deforestation and Forest Degradation (REDD+) program in the Philippines are ideal. REDD+ is a proposed climate change mitigation mechanism under the United Nations Framework Convention on Climate Change ('UNFCCC') that aims to transfer resources and incentivise cost-effective ways of avoiding deforestation in developing countries while also promoting conservation, restoration, and sustainable development.

It has since been recognised that the value-adding elements of REDD+ over other forest initiatives are: its attention towards the measurement, reporting and verification (MRV) of potential emissions reductions from REDD+ activities; and its social, governance, and environmental safeguards that include the requirement that any REDD+ programme ensure multi-stakeholder participation, respect for indigenous peoples' rights, consistency with national forest programmes and legislation, permanence and the nonconversion of natural forests. ${ }^{5}$

The REDD Plus program in the Philippines is anchored on the Philippine National REDD Plus Strategy ('PNRPS') ${ }^{6}$ that lays the framework for its eventual integration in the policies, programs and projects of the government and stakeholders. The PNRPS was initiated by a dynamic civil society movement - bolstered by a strong statutory framework for participatory, accountable and transparent governance in consultations, mapping and capacity building programs ahead of the Government action to formally usher in the REDD+ regime. The Philippines, a megadiversity country, is considered the third most disaster prone country in the world, and among the most vulnerable to the impacts of climate change. Its adoption of laws, policies and plans to strengthen its people's capacity to respond to the various climate and biodiversity challenges urgently demands a corresponding strengthening of the integrity of devastated ecosystems such as mangroves, peat lands and other wetlands forestry sector (mangroves, for brevity).

Embarking on the REDD+ program is ideal, as this will help address the challenging environmental, social and equity and governance issues in crafting the desired responses to climate change and disasters that impact heavily on the citizens and ecosystems of the Philippines. The program will help guide bold steps to respond and implement effective strategies in sustainably managing forest resources in the long-term, through a wide range of activities that reduce greenhouse gas emissions from deforestation and forest degradation and conservation, sustainable management of forests and enhancement of forest carbon stocks.

PNRPS describes the significant role of non-government organisations, including academe and people's organisations in its adoption, as follows:

Through these efforts, the CoDe REDD ${ }^{7}$ was formed to ensure that national REDD-plus developments yield co-benefits for biodiversity conservation and community development. After a series of workshops and increased interest from Government and the Department of Environment and Natural Resources-Forest Management Bureau (DENR-FMB), CoDe REDD partners identified the need to develop a multistakeholder REDD-plus strategy in order to facilitate REDDplus development in the Philippines; guide REDD-plus discussions within the development of the National Framework Strategy and Program on Climate Change; inform international donors and investors of country intentions; provide an initial national resource for domestic institutions interested in REDD-plus and for continued, broadened stakeholder engagement, and guide a future, targeted action plan. The involvement of the Climate Change Commission led to the integration of REDD-plus into Section 8.5 of the National Framework Strategy on Climate Change and to Executive Order 881 on REDD-plus planning and development. ${ }^{8}$

The PNRPS is a critical, accurate and timely assessment of the drivers of greenhouse gas emissions from deforestation and mangroves forest degradation in the Philippines. Inadequate and uncoordinated policy interventions on conservation and resource management, weak implementation of laws, overlapping of functions among agencies and, in general, poor management by the people and local governments had hindered the sustainable management of forests and caused their severe deterioration and loss.

\footnotetext{
A La Vina and L Ang, Implementing the REDD-Plus Safeguards: The Role of Social Accountability^(September 2011) The Red Desk <http://www.theredddesk.org/resources/reports/implementing_the_redd_plus_safeguards_the_role_ of_social_accountability_draft>.

${ }^{6}$ PNRPS <http://ntfp.org/coderedd/wp-content/uploads/2010/08/Philippine-National-REDD+-Strategy.pdf>.

${ }^{7}$ CoDe-REDD stands for Community Development through REDD, Communities Developing REDD Conservation and Development Through REDD <http://ntfp.org/coderedd/about-code-redd/background/>. ${ }^{8}$ Ibid.
} 
PNRPS puts forward strong core strategies for REDD+ development and for putting the country into a lowcarbon pathway. These strategies have seven overlapping components: enabling policy; governance; resource use, allocation and management; research and development; measuring, reporting and verification (MRV) of emissions reductions, and review procedures for non-carbon social and environmental impacts and benefits; sustainable financing; and capacity building and communication.

Since its adoption, encouraging developments have taken place that creates the hope of the PNSRP's achievability. National policies, exemplary local champions and private-public sector partnerships which adopt its key strategies, such as participatory planning and multi-stakeholder approaches, are emerging, indicating their viability, replicability and sustainability.

This paper focuses on the legal framework and the implications of certain key strategies, plans, programs for the conservation, enhancement and the sustainable management of mangroves as carbon sinks and as producers of essential but grossly undervalued goods and ecosystems services. The discussion encompasses a review of national laws and policies, if any, in relation to mangroves in the context of REDD+. In addition, it looks closely at a key element for strengthening and increasing the capacity of institutions through the indispensable role of engaged citizenry to exercise their right to participate in all phases of the policy process, from planning and implementation through to monitoring of programs.

\title{
The state of mangrove forests in the Philippines
}

The Philippines has a wide range of both freshwater or inland, and marine and coastal wetland ecosystems.

\section{Inland water ecosystems}

Inland water ecosystems are aquatic-influenced environments located within land boundaries. Examples of these are lakes, swamps and marshes, peat lands, river basins, reservoirs and dams. The PBCP ${ }^{9}$ includes 211 lakes varying from $.01 \mathrm{sq} \mathrm{km}{ }^{10}$ to $900 \mathrm{sq} \mathrm{km,} 18$ major rivers and 22 marshes, and swamps and reservoirs. ${ }^{11}$

These inland water ecosystems hosts a multitude of organisms including 316 fish species of which 121 are endemic and 76 are threatened and numerous species of waterbirds, aquatic plants and a majority of amphibians and semi-aquatic species such as the highly endangered Philippine crocodile (Crocodylus mindorensis). ${ }^{12}$

It is believed these are the most threatened of all ecosystem types. Threats to inland water ecosystems include pollution, habitat loss and degradation, resource use and exploitation, proliferation of alien invasive species, diversion of rivers for irrigation and dam construction, and the effects of climate change. Pollution largely comes from domestic and other non-point sources with considerable contribution from industrial and agricultural sources. ${ }^{13}$

\section{Coastal and marine wetland ecosystems}

Coastal and marine wetland ecosystems consist of coral reefs, mangroves, beach and beach forest, soft bottom communities including tidal flats, estuaries and seagrass beds, and open water areas. ${ }^{14}$

\begin{abstract}
Mangrove Forests - Forty of the 54 mangrove species in the world are found in the Philippines. There are current efforts to expand the coverage and strengthen the protection of mangrove areas in the country. This may suggest improvement of habitats for species that are mangrove dependent and consequently contribute to increase in fisheries stock and livelihoods. ${ }^{15}$
\end{abstract}

Mangroves have varying definitions under different statutes and under the PNRS, which defines them as 'forested wetland growing along tidal mudflats and along shallow water coastal areas extending inland along rivers, streams and their tributaries where the water is generally brackish and composed mainly of Rhizopora, Brugukm, Ceriops, Avicenia, Aegicerus, and Nipa species'. ${ }^{16}$ They are classified as part of the Philippine forest and provide protection as well as food for fish and other marine animals. They help

\footnotetext{
9 PBCP refers to Philippine Biodiversity Conservation Priorities.

${ }^{10}$ Refers to square kilometers

11 The National Wetlands Action Plan for the Philippines ('NWAP') 2011-2016. Part I: The State of Philippine Wetlands, p. 4 <http://www.psdn.org.ph/wetlands/nwap_phils_2011_part1.pdf>.

12 Ibid.

13 Ibid 5.

14 Ibid 15

15 Ibid.

${ }^{16}$ PNSRP, p. 66 < http://ntfp.org/coderedd/wp-content/uploads/2010/08/Philippine-National-REDD+-Strategy.pdf>.
} 
prevent coastal areas from soil erosion, act as filters, prevent the damaging effect of upland sediments on seagrass beds and coral reefs, minimise the effects of storm surges and mitigate climate change - acting as carbon sinks, estimated as capable of sequestering up to 25.5 million tonnes of carbon per year. ${ }^{17}$

The essential services they deliver are, however, easily destroyed through indiscriminate cutting, conversion of mangrove swamps to fishponds, reclamation projects and other coastal developments and pollution.

\section{Challenges}

The National Wetlands Action Plan for the Philippines 2011-2016 ('NWAP’) notes that:

Major threats to marine ecosystems and resources include: 1) human-induced and direct stresses on species and ecosystems such as deforestation, expanding human settlements, water pollution, overfishing and the use of destructive fishing methods; 2) those that can be attributed to climate change such as coral bleaching, eutrophication, dredging, siltation and sedimentation, nutrient loading, and sea level rise. ${ }^{18}$

\section{Major gaps}

NWAP identified major gaps in addressing the threats to coastal and marine wetlands: ${ }^{19}$

a) Biodiversity data gaps

- Lack of comprehensive data to better understand the state biodiversity of the selected coastal and marine ecosystems

b) Poor implementation of national laws and policies affecting the species and ecosystem diversity

c) On integrated coastal management (ICM)

- Disparity in the capacity among government agencies and coastal municipalities on the implementation of ICM plans as LGUs are expected to bear the cost of ICM implementation. Conflicts arise when some LGUs refused to allocate funds for ICM plan preparation and implementation

d) Capacity building on ecotourism planning and management, adaptation to climate change

e) Poor enforcement of coastal laws

f) Lack of land-based livelihood projects to limit extraction

There is an urgent need to look for solutions to address the aforementioned challenges. The Philippines has one of the longest coastlines in the world, ${ }^{20}$ in which more than 62 per cent of inhabitants dwell. ${ }^{21}$ The coastal or marine ecosystems, including the mangroves, are considered among 'the most productive and biologically diverse in the world', 22 but are in a dire condition.

'According to an FAO report in 2005 global mangrove coverage has fallen from 18.8 million hectares in 1980 to 15.2 million by the end of 2000 , corresponding to approximately 20 per cent of the global mangrove area in 1980 with Asia suffering the largest regional net loss' ${ }^{23}$ Mangrove forests have disappeared worldwide due to over-harvesting, the wood being used mainly for construction and burning. Large areas have been cleared for shrimp farming and aquaculture for other species, as well as for planting rice fields. This sad state is especially true in the Philippines. Aquaculture development in the Philippines results in 'more than 100,000 hectares of mangroves (being) converted into milkfish and shrimp ponds over the last 75 years' ${ }^{24}$

\footnotetext{
${ }^{17}$ B A Polidoro, et al, ‘The Loss of Species: Mangrove Extinction Risk and Geographic Areas of Global Concern' (2010) 5(4) PLOS ONE: e10095, doi:10.1371/journal.pone.0010095.

${ }^{18}$ NWAP, above $\mathrm{n} 11,16$.

${ }^{19}$ Ibid.

${ }^{20}$ A Briney, Longest Coastlines in the World, About.com.geography <http://geography.about.com/od/lists/a/longestcoastlines.htm>.

${ }^{21}$ Managing Philippine Coasts and Seas: Understanding the Challenge, One Ocean <http://www.oneocean.org/flash/the_philippine_seas.html>..

${ }^{22} \mathrm{~K}$ Kathiresan, Mangrove Ecosystems, 1 < http://ocw.unu.edu/international-network-on-water-environment-andhealth/unu-inweh-course-1-mangroves/Distribution-of-mangroves.pdf>.

${ }^{23}$ ZSL, Threats to Mangroves http<://www.zsl.org/conservation/regions/asia/mangrove-philippines/threats-tomangroves, 919,AR.html>.

${ }^{24}$ Ibid.
} 
Coastal development is another reason for deforestation. Hotels and residential areas are taking the place of mangroves, with profits as prime motivation and with minimal regard to the environmental effects.

In the Philippines, most of the proponents of the reclamation projects are officials of the local government units (LGUs) whose constituents include the poor and the displaced, and the neglected subsistence fisherfolk. This is ironic since the power and the responsibility for environmental protection and enforcement of anti-pollution laws, and the adoption of comprehensive land use plans have been devolved to LGUs under RA 7160, the Local Government Code ('Code').

A case in point is In Cebu, where a reclamation project has been started in one municipality that hosts one of the biggest seagrass ecosystems in the Visayas, which still has good mangroves and corals and with over 70 per cent of the constituents as fisherfolk and their families. The coastal municipality is adjacent to Olango Island Wildlife Sanctuary, one of the four Philippine wetlands of international importance recognised under the Ramsar Convention. The reclamation project was undertaken jointly by the provincial government and the municipality, and issued an environmental compliance certificate by the Department of Environment and Natural Resources despite the lack of use of a participatory process and the necessary prior approval of the Philippine Reclamation Authority. Moreover, under the Code, a national law and a plebiscite are required when there is substantial alteration of the territorial boundaries of the LGUs. It should be mentioned, likewise, that the ECC issued by the DENR did not even mention the impact of the reclamation on the Olango Island Wildlife Sanctuary.

As is happening all over the world, it bears repeating that 'the primary threats to all mangrove species are habitat destruction and removal of mangrove areas for conversion to aquaculture, agriculture, urban and coastal development, and overexploitation'. ${ }^{25}$

Climate change is also considered a threat to all mangrove species. 'With a rise in sea level, the habitat requirements of each species will be disrupted, and species zones will suffer mortality in their present tidal zones and attempt to re-establish at higher elevations in areas that were previously landward zones' ${ }^{26}$

\section{Legal regimes affecting the conservation of mangroves, peatlands and wetlands in the Philippines}

The Philippines is endowed with 216 lakes; 22 major marshes, swamps and reservoir; and 421 principal rivers. About 34 inland wetlands have been identified as priority sites for research and conservation by the Philippine Biodiversity Priority Setting exercise. Seven (7) of these are now considered Key Biodiversity Areas (KBAs) while another 14 lakes are considered as Candidate Key Biodiversity Areas (CKBA). There are four (4) Philippine wetlands of international importance recognized under the Ramsar Convention, namely: Tubbataha Reef Natural Park in Palawan, Olango Island Wildlife Sanctuary in Cebu, Naujan Lake National Park in Oriental Mindoro, and Agusan Marsh Wildlife Sanctuary in Northeastern Mindanao. ${ }^{27}$

Wetlands' services include flood control, groundwater replenishment, water purification, sediment and nutrient retention and export, reservoirs of biodiversity, shoreline stabilisation/storm protection, climate change mitigation and adaptation, cultural values recreation and tourism, and wetland products.

Wetlands may store as much as 40 per cent of global terrestrial carbon; peatlands and other forested wetlands are particularly important carbon sinks. The conversion to agricultural use and destruction of wetlands releases large quantities of carbon dioxide, the gas that accounts for 60 per cent of the global warming effect. ${ }^{28}$

Are wetlands, mangroves and peatlands adequately protected by statutes? Undeniably, there is a strong legal framework for the protection of environmental rights, conservation of natural resources, and, lately, the country's response to climate change. There is even a social justice provision in the Constitution guaranteeing the preferential rights of fisherfolk to access their traditional fishing grounds. The Constitution and various laws guarantee both substantial and procedural rights for their exercise and protection.

\footnotetext{
${ }^{25}$ Primavera, above n 1,6

${ }^{26}$ Ibid.

${ }^{27}$ NWAP, above n 8 .

28 Ibid.
} 


\section{Laws related to climate change response}

Laws on climate change (including recent amendments) and disaster risk reduction and management (DRRM) had been crafted. In relation to a Climate Change response, the relevant laws are the Climate Change Act, as amended, and the Disaster Risk Reduction and Management Law that identifies the need for mangrove protection and rehabilitation as both mitigating and adaptive measures to climate change. Other policy interventions are in the form of issuances from the Office of the President, and the Philippine Climate Change Commission (Commission) and, of course, the Philippine National Strategy for REDD+.

In August, 2012, the President signed RA 10174 which amended the RA 7924, of the Climate Change Act. The statute harmonises laws and policies related to climate change and disaster risk reduction and management. ${ }^{29}$ It gave broader powers to the Commission as 'the lead policy-making body of the government, which shall be tasked to coordinate, monitor and evaluate the programs and action plans of the government in order to ensure the mainstreaming of climate change into the national, sectoral and local development plans and programs'. ${ }^{30}$

The Commission has promulgated the National Framework Strategy on Climate Change 2010-202 ('NFSCC') which adopted REDD+ as both a mitigating ${ }^{31}$ and adaptation ${ }^{32}$ strategy 'by enhancing ecosystem services and establishing safeguards towards the realisation of multiple environmental and social benefits'. ${ }^{33}$

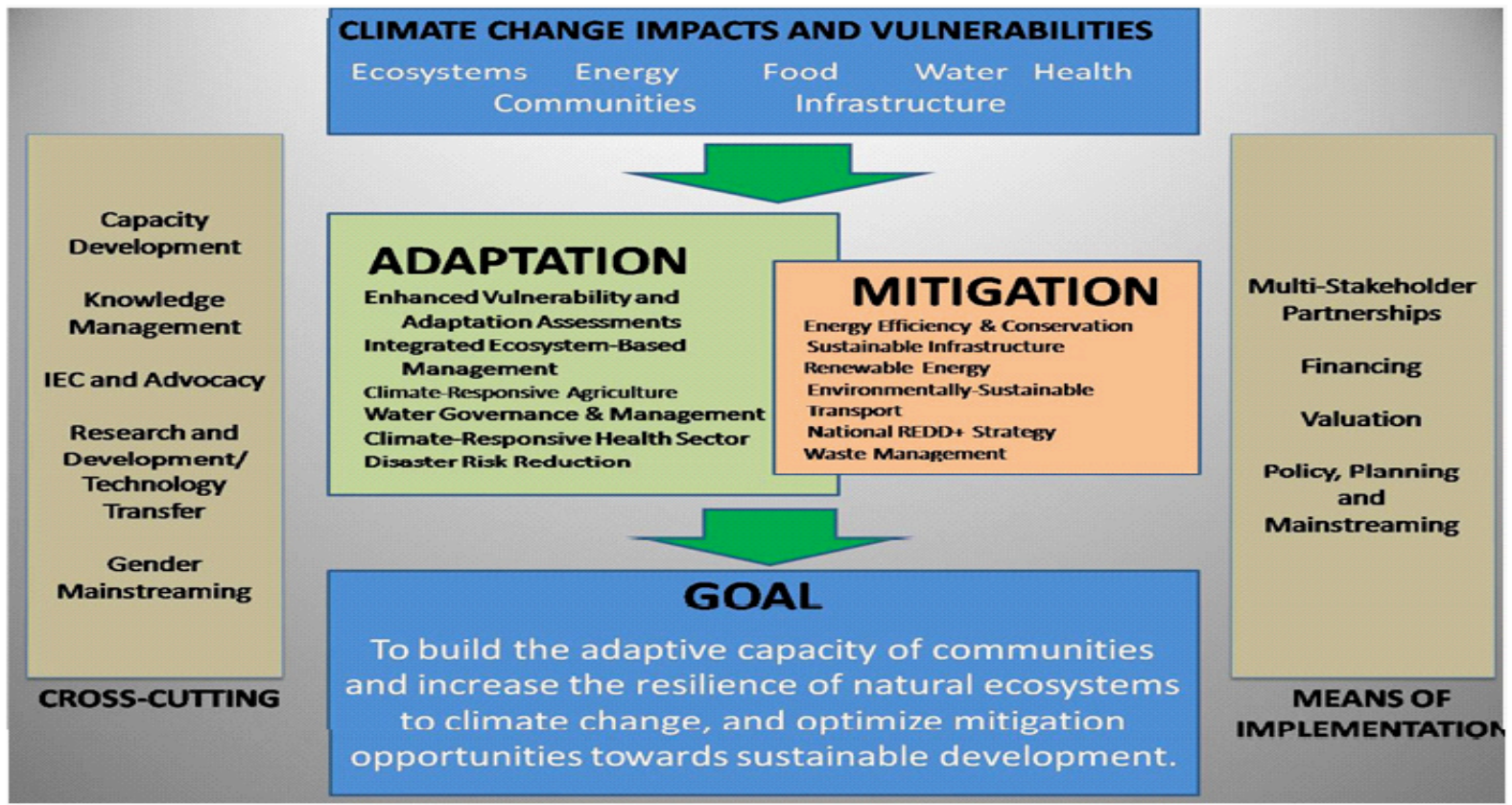

Figure 1: Operational Diagram of the NFSCC ${ }^{34}$

Under the National Climate Change Action Plan ('NCCAP'), the implementation of National REDD+ is a goal and a key activity under the objective of enhancing resiliency and stability of natural systems and communities, illustrated by Figure 2 .

To prioritise the allocation and availability of funds for the implementation of these climate related plans and programs, RA 10174 integrated 'Climate Finance, ${ }^{35}$ and created the mechanisms for utilisation of the

\footnotetext{
${ }^{29}$ Former President Arroyo signed RA 10121, the Disaster Risk Reduction and Management Law, in 2010 <http://www.lawphil.net/statutes/repacts/ra2010/ra_10121_2010.html>.

${ }^{30}$ RA 10174, s 3 thereof, amending s 4 of the Climate Change Act < http://www.gov.ph/2012/08/16/republic-act-no$10174 />$.

${ }^{31}$ NFSCC, s 7 (Synergy of Adaptation and Mitigation), a portion of which states that 'adaptation is as much a development concern as mitigation. With the context of global-scale shifts in the climate system, development can only succeed if mitigation strategies such as energy efficiency and conservation, renewable energy development, environmentallysustainable transport, sustainable infrastructure, and Reduction of Emissions from Deforestation and Forest Degradation (REDD+) are undertaken in the context of adaptation. The development of a framework that integrates adaptation within the development process is deemed to ensure sustainability and success (WRI, 2007).

32 lbid, s 8.

33 Ibid.
}

${ }^{34}$ Ibid 17. 
People's Survival Fund. It is a special fund in the National Treasury with an annual appropriation of One Billion Pesos 'for the financing of adaptation programs and projects based on the National Strategic Framework'. ${ }^{36}$

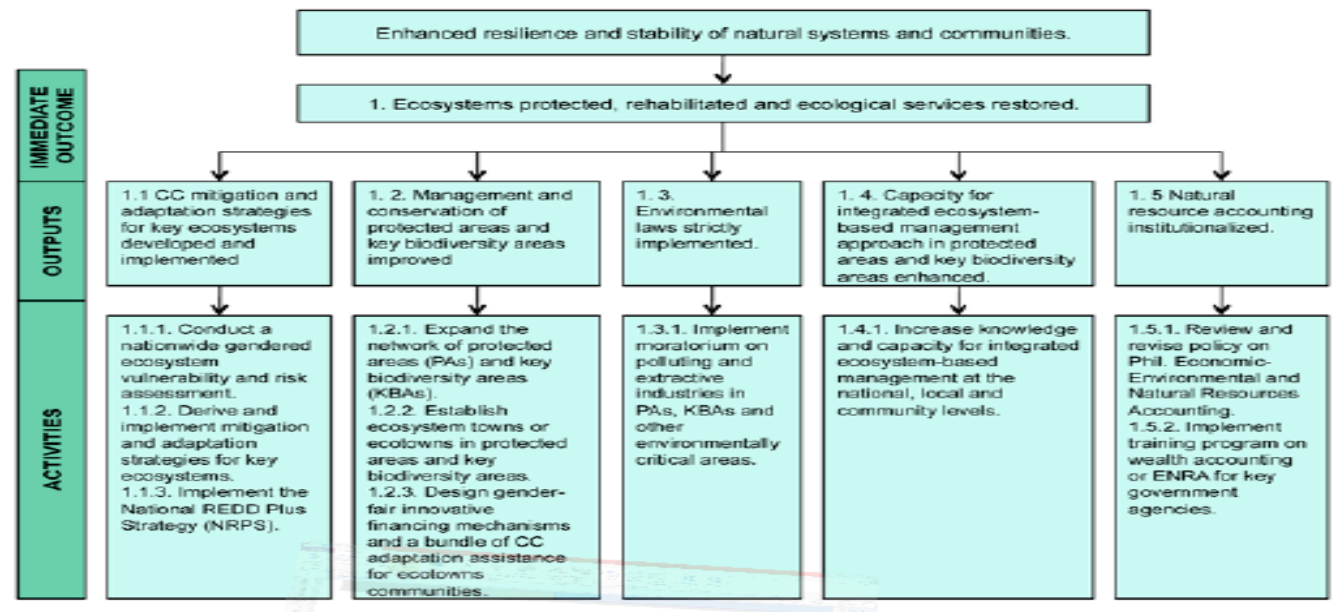

Figure 2: Strategic actions on ecosystem resilience and environment stability for 2011-2028, NCCAP ${ }^{37}$

\section{Applicable laws on natural resources conservation}

The laws with provisions for the general protection and conservation of mangroves include the Fisheries Code, the Forestry Reform Code, the National Integrated Protected Area System Act and the Wildlife Conservation and Protection Act. A provision in the National Internal Revenue Code (Republic Act 7161), which amends certain provisions of the Forestry Reform Code, actually provides for the express prohibition on the cutting of all species of mangroves, without distinction or qualification. This is further reinforced by the Fisheries Code. ${ }^{38}$

Clearly, the regulations declare that:

1. All mangrove swamps set aside for coastal protection purposes shall not be subject to clear-cutting operation.

2. Mangrove and other swamps released to the Bureau of Fisheries and Aquatic Resources for fishpond purposes which are not utilised, or which have been abandoned for five years from the date of such release shall revert to the category of forest land. ${ }^{39}$

3. It shall be unlawful for any person to convert mangroves into fishponds or for any other purposes. ${ }^{40}$

Violation of the provision entailed imprisonment of six years and one day to twelve years and/or a fine of eighty-thousand pesos (P80,000.00), and if the area requires rehabilitation or restoration as determined by the court, the offender would also be required to restore or compensate for the restoration of the damage.

\section{Other Applicable Regulations}

\section{Executive Orders under the Aquino administration}

\section{Executive Order No 26 on the National Greening Program ('NGP')}

Declaring that poverty reduction, resource conservation and protection, productivity enhancement, climate change mitigation and adaptation are among the priority programs of the Aquino administration, the NGP requires the planting of 1.5 billion trees covering around 1.5 million hectares for a period of six years from 2011 to 2016 in forestlands, mangrove and protected areas, ancestral domains, civil and military

\footnotetext{
${ }^{35}$ Refers to resources that have been allocated or may be utilised towards the climate change adaptation and mitigation requirements of the country and its vulnerable communities.

${ }^{36}$ RA 10174, ss 18-20, above N 31.

${ }^{37}$ Summary of National Climate Change Action Plan, 9 <http://www.dilg.gov.ph/PDF_File/resources/DILG-Resources2012116-d7b64f9faf.pdf>.

${ }^{38}$ Fisheries Code, s 94: Conversion of mangroves into fishponds and/or any other use or purpose.

39 Ibid, note 1 , s 43.

${ }^{40} \mathrm{PD} 705$, s 94 .
} 
reservations, urban areas under the greening plan of the LGUs, inactive and abandoned mine sites, and other suitable lands.

The NGP aims, likewise, to address poverty issues by making all proceeds from agroforestry plantations accrue to the NGP beneficiary communities to address food security and poverty reduction. These NGP beneficiary communities are considered priority in the Conditional Cash Transfer (CCT) Program. The CCT Program, known as the 'Pantawid Pamilyang Pilipino Program' (4Ps) is described as 'a human development program of the national government that invests in the health and education of poor households, particularly of children aged 0-14 years old. Patterned after the conditional cash transfer scheme implemented in other developing countries, the 4Ps provides cash grants to beneficiaries provided they comply with the set of conditions required by the program. ${ }^{41}$

Executive Order No 23, February 01, 2011 ('EO 23')

EO 23 declares a moratorium on the cutting and harvesting of timber in the natural and residual forests. The DENR is mandated to strictly implement a forest certification system in accordance with the United Nations standard/guidelines to ascertain the sustainability of legal sources and the chain of custody of timber and wood products nationwide. The DENR is directed to close and disallow the operation of all sawmills, veneer plants and other wood processing plants that are unable to present proof of sustainable sources of legally cut logs for a period of at least five years within one month from implementation of the EO.

\section{Executive Order N 79, s of 2012 ('EO 79')}

The following areas are declared closed to Mining Applications for mineral contracts, concessions, and agreements:

a) Areas expressly enumerated under section 19 of RA No 7942, the Mining Law of 1995 which covered '(f) Old growth or virgin forests, proclaimed watershed forest reserves, wilderness areas, mangrove forests, mossy forests, national parks, provincial/municipal forests, parks, greenbelts, game refuge and bird sanctuaries as defined by law in areas expressly prohibited under the National Integrated Protected areas System (NIPAS) under Republic Act No. 7586, Department Administrative Order No. 25, series of 1992 and other laws'.

b) Protected areas categorised and established under the National Integrated Protected Areas System (NIPAS) under RA No. 7586.

C) Prime agricultural lands, in addition to lands covered by RA No. 6657, or the Comprehensive Agrarian Reform Law of 1988, as amended, including plantations and areas devoted to valuable crops, and strategic agriculture and fisheries development zones and fish refuge and sanctuaries declared as such by the Secretary of the Department of Agriculture (DA);

d) Tourism development areas, as identified in the National Tourism Development Plan ('NTDP'); and,

e) Other critical areas, island ecosystems, and impact areas of mining as determined by current and existing mapping technologies, that the DENR may hereafter identify pursuant to existing laws, rules, and regulations, such as, but not limited to, the NIPAS Act.

\section{Other pertinent administrative regulations for the protection of Mangroves can be} found in Primavera's Table of Philippine Mangrove Greenbelt/Other Laws.

Table 1: Philippine Mangrove Greenbelt/Other Laws (Primavera et al., 2004) (2 $^{42}$

Presidential Decree 705 (1975) Revised Forestry Code; mangrove strips in islands providing protection from high winds, typhoons shall not be alienated

Presidential Decree 953 (1976) Fishpond/mangrove lease holders required to retain or replant 20-m mangrove strip along rivers, creeks

BFD A.O. 2 (1979)

Min. $25 \%$ of total mangrove forest in given area completely protected as Mangrove Wilderness Area

P.P. $2151 \& 2152(1981)$

Declaration of 4,326 ha mangroves as wilderness areas, 74,767 ha as forest reserves

\footnotetext{
${ }^{41}$ DSWD, Pantawid Pamilyang Pilipino Program <http://pantawid.dswd.gov.ph/index.php/about-us>

$42 \mathrm{~J}$ Primavera, Mangroves and Aquaculture in Southeast Asia, 10, 2005 <http://repository.seafdec.org.ph/bitstream/handle/10862/711/RTCCode_p25-37.pdf?sequence=1>
} 


\begin{tabular}{ll}
\hline MNR A.O. 42 (1986) & $\begin{array}{l}\text { Expansion of mangrove belot in storm surge, typhoon areas: } 100 \mathrm{~m} \text { along } \\
\text { shorelines, } 50 \mathrm{~m} \text { along riverbanks }\end{array}$ \\
\hline DENR A.O. 76 (1987) & $\begin{array}{l}\text { Establishment of buffer zone: } 50 \mathrm{~m} \text { fronting seas/oceans and } 20 \mathrm{~m} \text { along } \\
\text { riverbanks; lessees of FLA ponds required to plant 20-50-m mangrove } \\
\text { strip }\end{array}$ \\
\hline DENR A.O. 77 (1988) & $\begin{array}{l}\text { Integrated Social Forestry Program (provision of legal tenure incentives } \\
\text { for co-management of forest resources) }\end{array}$ \\
\hline DENR A.O. 123 (1990) & $\begin{array}{l}\text { Award of 25-yr Community Forestry Management Agreement for small- } \\
\text { scale mangrove use, Rhizophora and Nypa plantations, aquasilviculture }\end{array}$ \\
\hline DENR A.O. 15 (1990) & $\begin{array}{l}\text { Policies on communal forests, plantations, tenure through Mangrove } \\
\text { Stewardship Contracts; revert abandoned ponds to forest; ban cutting of } \\
\text { trees in FLA areas; prohibit conversion of thickly vegetated areas }\end{array}$ \\
\hline DENR A.O. 3 (1991) & Policies and guidelines for Mangrove Stewardship Agreement \\
\hline CENR A.O. 23 (1993) & $\begin{array}{l}\text { Combined 3-yr Mangrove Reforestation Contract and 25-yr Forest Land } \\
\text { Management Agreement into 25-yr FLMA for families (1-10 ha) and } \\
\text { communities (10-1,000 ha) }\end{array}$ \\
\hline
\end{tabular}

\section{No national policy specifically on mangroves, peat lands and wetlands}

The country has the laws to protect and conserve mangroves but these are scattered in different statutes and administrative regulations. It is a disturbing fact that there is no singular legal document that consolidates all national policies on conservation and protection of mangroves, peatlands and wetlands. Some wetlands have a special law to govern their management such as the multi-awarded Tubbataha Reef Natural Park in Palawan. ${ }^{43}$ Most like the Olango Island Wildlife Sanctuary have none.

This, sadly, reveals the lack of attention, appreciation and prioritisation given to these nurturing habitats of biodiversity, the important ecosystem services they provide and their distinct role in climate mitigation and adaptation. It is not a source of wonder then that they are easily sacrificed in the altar of 'progress, profit and profligate consumerism' - at a tremendous cost.

This worrisome state is acknowledged no less in the NWAP that affirmed that ' $[\mathrm{A}] \mathrm{t}$ present, there is no overall national policy on wetlands in the Philippines'. It notes that 'Profiling even just the major wetlands of the Philippines is a major undertaking that will take considerable time and resources ... Although there are a number of studies that generated information about selected wetlands, these are sporadic and fragmented'. ${ }^{44}$

The NWAP is intended to be 'the guiding document for the Philippines to promote and implement strategies and actions for the conservation and wise use of its wetlands, incorporating urgent concerns such as biodiversity conservation and climate change mitigation and adaptation' ${ }^{45}$ But, without a guiding statutory framework for mangroves, peatland and wetland, their protection and management are at best left to chance, continuing challenges and, perhaps, irreversible destruction.

NPSRP recommends, in addition, a review of forestry sector definitions, noting that 'Many formal definitions within the forest sector lack clarity or are contradictory, which is a problem both domestically and at the international level. There is a need to review existing definitions and engage with diverse stakeholders to adopt a coherent, updated list of national definitions, which should also conform to international standards'. ${ }^{46}$

\section{The REDD+ and mangroves}

The PNSRP follows a three-phased approach for the implementation of REDD (See Figure 3).

The considerable period of a maximum of five years for the 'readiness' phase is ample time for all stakeholders to prepare for the 'implementation' stage. The government can still craft the necessary laws

\footnotetext{
${ }^{43}$ R A 10067, Known as the Tubbataha Reefs Natural Park Act of 2009 ('TRNP') <http://www.lawphil.net/statutes/repacts/ra2010/ra_10067_2010.html>.

${ }^{44}$ NWAP, above $\mathrm{n} 11,3$.

45 Ibid.

${ }^{46}$ National Philippine Strategy for REDD PLUS ('NPSRP') Philippines. Key definitions for review include 'forest', 'deforestation/deforested land', 'forest degradation/degraded forest', 'reforestation' and 'restoration'.
} 
and policies, such as the National Law for the Conservation and Protection of Mangroves, Peat lands and Wetlands. With so much space for engagement in activities under REDD+, civil society institutions are expected to engage more with the public and private sectors in the strategies under: enabling policy; governance; resource use, allocation and management; research and development; MRV of emissions reductions and review procedures for non-carbon social and environmental impacts and benefits; sustainable financing, and capacity building and communication.

NPSRP puts it succinctly:

Existence of enabling laws and good policies is insufficient. Robust leadership; democratic and participatory governance; political will; and both new and strengthened institutional arrangements will be essential to creating and operationalizing REDD-plus policies. Many of the existing drivers of deforestation and degradation are linked to the inability to effectively operationalize existing legislation and policies. These links and ensuing failures need to be clearly articulated, which will form part of the policy reviews discussed in the 'Policy' component. As a performance-based initiative, REDD-plus has unique potential to help motivate follow-through and policy implementation at multiple scales. ${ }^{47}$

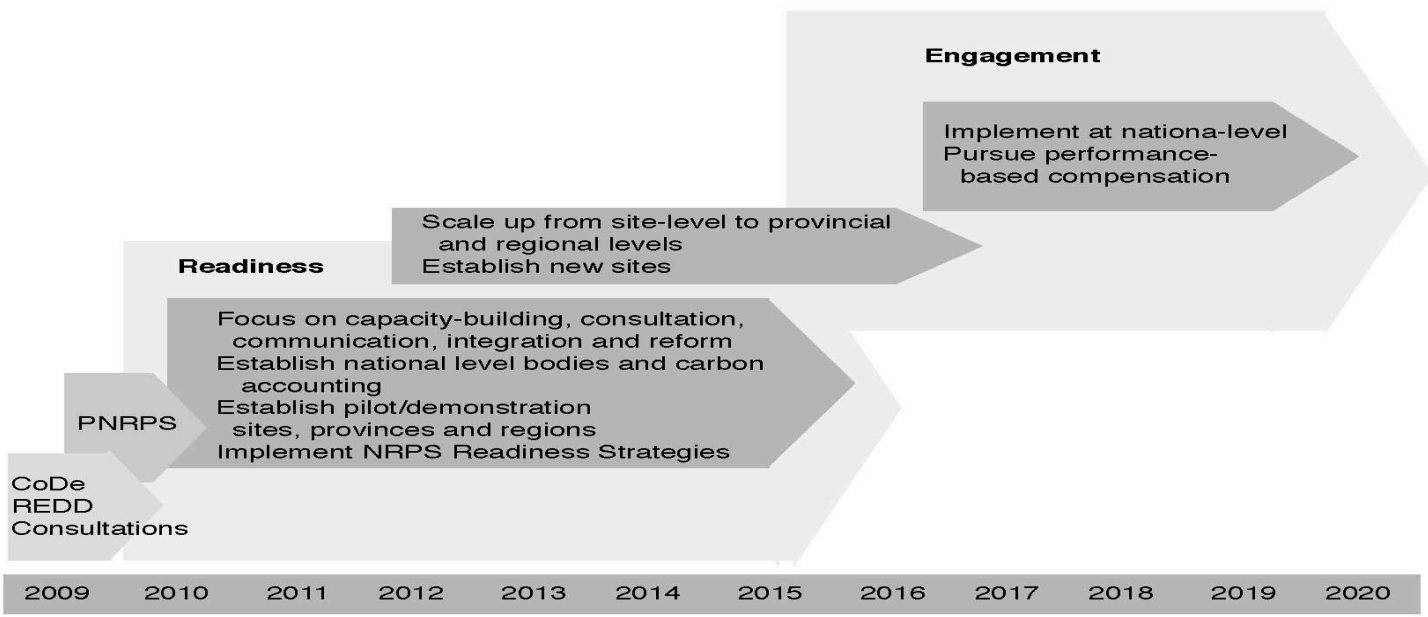

Figure 3: Anticipated timeline of REDD+ development in the Philippines ${ }^{48}$

\section{Emerging trends: Private sector role in conservation and sustainable management of mangrove forests}

The Copenhagen Accord (REDD+) hopes to expand the role of the private sector in conservation and sustainable management of forests, making the sector part of the climate change solution. It presents opportunities for collaboration in forestry sector initiatives in developing countries, including the Philippines. Despite relatively limited remaining natural forest cover, the Philippines' NGO sector is actively supporting various initiatives to enhance forest stocks through reforestation, adaptive watershed management, national greening programs, public-private sector partnerships for forest restoration, and the like.

In key biodiversity areas around the country, NGOs in partnership with private companies are implementing REDD + related projects to help conserve and sustainably manage forests, including mangroves. These types of projects not only encourage corporate social responsibility but also establish partnerships for sustainable enhancement of natural forest cover.

\footnotetext{
47 PNRPS, 40.

${ }^{48}$ The Philippines REDD-Plus Strategy Team, 'The Philippine National REDD-plus Strategy' (Department of Environment and Natural Resources-Forest Management Bureau and CoDe REDD-plus Philippines) 17 <http://ntfp.org/coderedd/wpcontent/uploads/2010/08/Philippine-National-REDD+-Strategy.pdf>.
} 
Mangroves are unique and valuable ecosystems that functionally support a wide variety of nearshore fisheries and ecological services, especially to coastal communities in the Philippines. They serves as nursery and breeding areas as well as provides shoreline protection from storms, wave action and strong winds. In the Philippines, the nursery and habitat role provided by mangroves for fish is estimated at an annual value of PHP 5.6 mil (USD 130, 593). Hence, in terms of management efforts, the protection and conservation of mangroves should be prioritized.

Due to the important role of the mangrove ecosystem, NGOs like the Coastal Conservation and Education Foundation (CCEF) have embarked on 'Adopt-A-Mangrove' projects (Figure 5) that aim to encourage private sector participation to restore dwindling mangrove areas in coastal areas located at Cebu and Batangas. These initiatives influenced partners from the business sector to invest in mangrove rehabilitation projects especially in highly degraded coastal areas in the Philippines. CCEF has now collaborated with a number of business groups such as Timex Philippines, National Grid Corporation of the Philippines, Accenture, and Harbor Star Shipping Services through their Corporate Social Responsibility (CSR) programs.

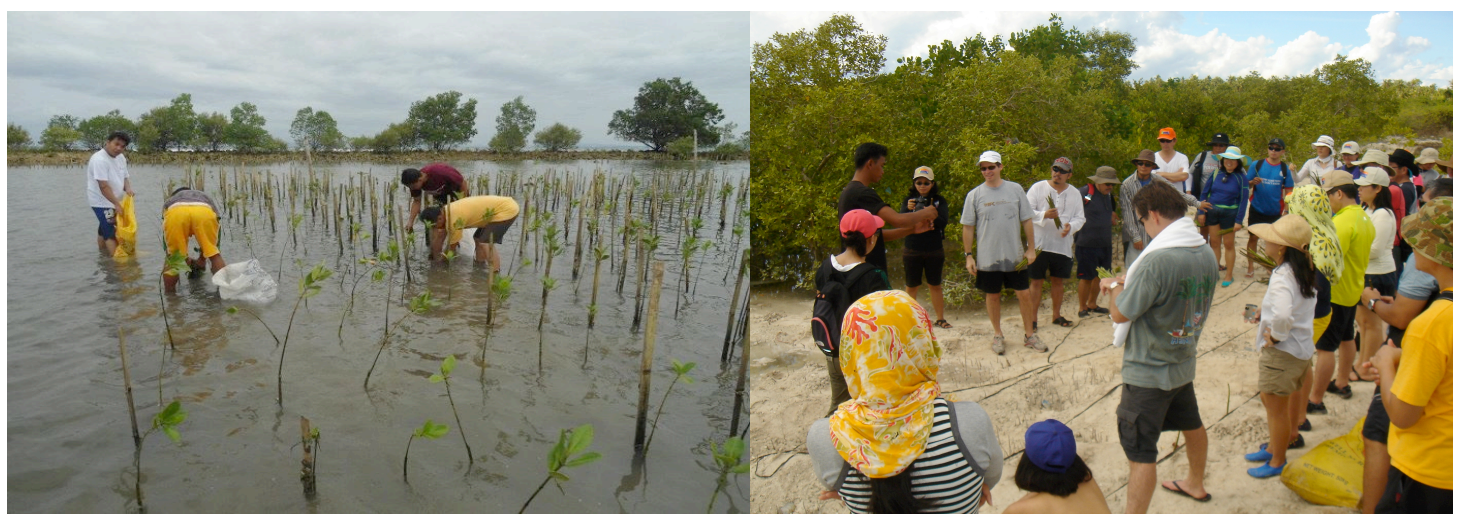

Figure 5: Adopt-a-mangrove activities of CCEF with private sector groups

\section{San Francisco, Camote Island, Cebu-San Fran system of governance}

San Francisco in Cebu won the 2011 UN Sasakawa Award for Disaster Risk Reduction and management for its pioneering, innovative and empowering San Fran Purok System of governance. The active participation of citizens in the purok, the sub-political units of barangays, is widely acknowledged as a model of sustainable governance. It is a merging of the bottom-up and top-down leadership. In an interview, San Francisco Vice Mayor, Al Arquillano, who was then the Mayor who conceptualised and implemented the program, said that 'only Sanfran System has a unique approach of empowering community with the combination of the top down and bottom up approach of governance that it is tested and proven based on our experience'. ${ }^{49}$

Bangladesh and Sri Lanka have shown interest or are also implementing the San Fran way. The Sanfran System is already adopted by UNISDR.

Using the San Fran system, the municipality of San Francisco (Philippines) embarked on the Two Million Trees Project for Greening San Francisco 13 October 2010. This program involves specifically mangrove reforestation, conservation and management. According to Vice Mayor Al Arquilano, 'at present, there is an increased number of people participation and the system is being institutionalized not only in the LGU but in the life of the every family living in San Francisco'. ${ }^{50}$ In the implementation of the program, the municipality coordinates and collaborates with the Department of Agriculture, DENR and Climate Change Commission. There is also support from UNISDR.

According to Vice Mayor Arquillano, 'the Two Million Trees Project for Greening San Francisco is not only addressing carbon stocks enhancement, mitigating the flood impact and global warming but it generates income for the vulnerable family through Cash for Work Program so that they can support the schooling of their children'. ${ }^{51}$ He is referring to the Conditional Cash Transfer Program integrated in the National

\footnotetext{
${ }^{49}$ A Arquillano (personal communication, 03/11/2012).

50 Ibid.

51 Ibid.
} 
Greening Program under the Aquino Administration. Poverty alleviation and ecological integrity through public participation are critical elements that make the REDD+ Program sustainable.

The challenges he mentioned for REDD+ implementation are the limited budget allocation, the absence of designated Forest Guard that will provide full time care for the trees planted in the public area or the timberland, and the lack of technical expertise in carbon emission calculation. He sees the San Fran system of governance as key to sustainability of any program, including REDD+: '[t]he sustainability of every project lies on the bulk of the community participation and involvement. Only Sanfran System has a unique approach of empowering community with the combination of the top down and bottom up approach of governance that it is tested and proven based on our experience'. ${ }^{52}$

Learning from the lessons of local experiences and practices, and the insights from practitioners implementing aspects of the REDD+ programme, more stakeholder awareness and participation on REDD+ are invaluable steps that the government should take during the crucial REDD readiness phase.

Given the infancy of REDD experiences, however, it is important to allow time for governments to experiment and learn from experience in pilot projects, as well as to build capacity of the administration and relevant stakeholders. A preliminary 'trial and error' phase of REDD will offer governments an opportunity to refine more precise legal instruments needed for implementation at the national and sub-national level of REDD activities. ${ }^{53}$

Countries with more stable investment environments, land ownership and use rights, and clear, wellenforced regulatory frameworks are expected to reap the greatest opportunities from REDD. ${ }^{54}$

\section{Conclusion and recommendation}

NGO-private sector partnership models are the necessary collaborative effort that REDD+ programs require to mainstream climate change solutions and ecosystem resilience. This kind of complementary work contributes tp pushing forward the country's initiatives towards conserving and sustainably managing forest carbon stocks. However, the key elements remain: leadership of both national and local levels to seriously implement environmental laws and the National REDD+ Strategy; harmonisation of policies and projects under the NFSCC and NCCAP to build the resiliency of ecosystems and the people; and continuously building the capacity of stakeholders and institutions to effectively manage ecosystems, taking into consideration ecosystem services. The benefits of protecting mangrove resources can continue and be sustained only if appropriate efforts are undertaken by effective collaboration and engagement of stakeholders, the continuing display of fortitude and political will of both political authorities and the citizenry, and responsive, transparent, accountable and participatory governance.

Finally, it should be emphasised that:

For successful REDD regimes, national governments should guarantee that forests remain intact and standing on a permanent basis. This outcome is more likely to occur via: fair and effective treatment of ownership and land ownership and use rights; benefit sharing; monitoring, reporting, and verification (MRV); access to information; and guarantee of public participation in future REDD national legal frameworks. Although the greatest attention currently focuses on changing the behaviours of countries with the highest deforestation rates, a well-designed international REDD regime should also seek to reward countries traditionally maintaining their forests, so that they are not under pressure to cut their own forests. Furthermore, while the international REDD regime may focus primarily on carbon stocks and flows, the national legal frameworks should approach REDD within the broader concept of governance of ecosystem services, accounting for the intrinsic values of forests and their services. ${ }^{55}$

\footnotetext{
${ }^{52}$ Ibid.

53 John Costenbader (Ed.), Legal Frameworks for REDD. Design and Implementation at the National Level (IUCN, Gland, Switzerland, 2009) xiv + 200, 13 <http://data.iucn.org/dbtw-wpd/edocs/EPLP-077.pdf>.

${ }^{34}$ Ibid p.5.

55 Ibid.
} 